\title{
Presenting an algorithm of integer nonlinear multiple objective programming in conditions of uncertainty for balanced scorecard method (case study in Islamic Azad University, Semnan Branch)
}

\author{
Mohammad Hemati ${ }^{\mathrm{a}}$ and Hamidreza Karkehabadi ${ }^{\mathrm{b}}$
}

${ }^{a}$ Assistant Professor, Department of Industrial Management,Semnan Branch, Islamic Azad University, Semnan, Iran ${ }^{b}$ Department of Industrial Management. Member of Young Researchers Club, Islamic Azad University, Semnan Branch, Iran

\begin{tabular}{|c|c|}
\hline AR T I C L E I N F O & A B S T R A C T \\
\hline $\begin{array}{l}\text { Article history: } \\
\text { Received October } 1,2011 \\
\text { Received in Revised form } \\
\text { November, } 14,2011 \\
\text { Accepted } 30 \text { January } 2012 \\
\text { Available online } \\
\text { 20 February } 2012 \\
\text { Keywords: } \\
\text { Fuzzy set covering problem } \\
\text { Balanced scorecard method } \\
\text { Non-linear multiple objective }\end{array}$ & $\begin{array}{l}\text { Balanced scorecard is a performance appraisal method planned for measuring the } \\
\text { organizational efficiency to develop their strategies. Organization's strategies in a specified } \\
\text { period are the main inputs in this model. Furthermore, due to nature, experts' opinions play the } \\
\text { vital role in determining the strategies. In this research, the proposed algorithm is designed by } \\
\text { using fuzzy set covering problem and non-linear multiple objective integer programming (zero } \\
\text { and one variables), so that it can be useful to choose the best combination of strategies for } \\
\text { specified period of time with the least deviation in experts opinions. The presented model is } \\
\text { carried out in Islamic Azad University, Semnan Branch. The results indicate that the designed } \\
\text { model can provide the best combination of strategies for entering into the balanced scorecard } \\
\text { system. }\end{array}$ \\
\hline
\end{tabular}

integer programming (zero and one variables)

Fuzzy programming

\section{Introduction}

Since no organization has unlimited resources and present business environment is severe competitive environment, developing competitive strategies is very important to help organizations achieve their targets. In fact, using limited resources on non-strategic fields will result in surrendering opportunities to those competitors who concentrated their resources on strategic issues. Hence, organizations implementing incorrect strategies claim that if they knew the things the way they should, they would do the tasks differently (Lee \& Ko, 2000). In strategic approach, there is a strong principle, that is, concentration. If we want to be strong in all fields, it is not possible to be strong at all of them. This principle arises from competitive environment and limitation of resources, from which the generative strategies stem. Therefore, organizations will not be able to develop all specified strategies at the strategy developing stage; they should focus on strategies having the most impacts on the future organization's success.

\footnotetext{
* Corresponding author

E-mail addresses: mo928hem@yahoo.com; m.hemati@semnaniau.ac.ir (M. Hemati) 
If organizations want to consider all strategies in their approach toward balanced assessing, besides the limited resources and competitive environment, they will face a large number of strategic actions, targets and criteria, and the balanced scorecard method will miss its efficiency.

Another important issue that has received less attention is the expert team's opinions in developing the strategies. Even though the expert team's opinion has the biggest impact in strategy development, the decrease of existing errors in survey process and combination of the expert team's opinion has received the minimum attention. We know human preferences are always under uncertainty, which are qualitative descriptions that allotting exact numerical values to them is not easy task. Therefore, verbal phrases have been used in the frame of fuzzy hypothesis for resolving this ambiguity in data. Fuzzy hypothesis can be applied for ambiguity or non-clear judgments in the form of mathematics (Tseng et al., 2009; Tseng \& Lin, 2009) but the amount of deviation in experts' opinion related to each of the strategies is an untapped subject.

Therefore, in this research, we try to reinforce the previous models in increasing the aggregative agreements, considering the good points of the last related models. This has been done by using an algorithm, which is a combination of multiple objective integer programming and fuzzy set-covering problem. The main properties of the proposed algorithm are as follows; it decreases the implementation costs, increases the aggregative agreement, and minimizes the deviation of experts' views.

This article has five parts. In the second part, the definitions and concepts are presented. In the third and forth parts, the conceptual model and its implementation steps are analyzed. The model has been applied in the Islamic Azad University, Semnan Branch. The results has been presented in the fifth part

\section{Methods of performance appraisal}

Literature in performance appraisal has two stages. In the first stage that lasted until 1980s, the center of attention has been financial criteria. In the second stage that began late 1980s, financial measurement has had many changes and interest to this area has increased, considerably. Even some researchers remind this stage as appraisal measurement revolution (Baldwin \& Clark, 1992).

Changes that occurred on measurement during these years caused a move from traditional measurement to balanced measurement (Wilson, 2004; Gumbus, 2005). These Changes started when the results of researches in this area indicated that 70 percent of developed strategies at implementation stage have encountered failure. This means that implementation of developed strategies is more difficult than developing good strategies. These problems caused a model that has been presented at early $1990 \mathrm{~s}$ for appraisal performance of organizations and strategies implementation called balanced scorecard.

\subsection{Balanced scorecard method}

BSC is an important activity in organization for continuous improvement emphasizing on performance appraisal (Tseng et al., 2008; Tseng, 2009). In this model, apart from financial perspective, used traditionally for performance appraisal of organizations, three other perspectives are used for it, which are customer, internal processes, innovation, and learning. Kaplan and Norton, accounting professors of Harvard University, are designers of this model. They understood the limitations of performance appraisal with sole financial indicators, so they introduced balanced scorecard, as a new managerial tool for performance appraisal, in 1992 in their article in "Harvard Business Review". They developed balanced scorecard as a tool for designing strategies, developing them in an organization and as a managerial controlling tool, by publishing three more articles in 1993, 1994 and 1996. In this model, we can implement strategies in innovative ways, with an

emphasis on cause and effect relationships between these four aspects, described in a road map for 
various managerial levels and determining the strategic goals, quantitative goals, measurement criteria, \& objects in each of these four aspects and in all levels.

Nowadays, balanced scorecard is known as one out of fifteen managerial tools that are useful, least error and effective tools between managers of different companies in 22 countries around the world. Researches show that 70 percent of American companies have used this tool or they are going to use it (Niven, 2003; Kaplan \& Norton, 2001). However, still less study has been done on development and implementation of BSC in appraising the performance of academic activities (Tseng, 2010).

Kaplan and Norton believe the first step in achieving the BSC goals is to determine the organizations' visions \& strategies (Kaplan \& Norton, 1996). This method has helped the management of the organizations through clear and non-contradictory explanation of strategy. Before introducing balanced scorecard method, managers did not have any generally accepted framework for explaining strategy, hence unable to implement what they could not explain (Kaplan \& Norton, 2001; Kaplan \& Norton, 2004). In reality, BSC is a management system that can explain organizational visions and strategies clearly and translate them into operational programs.

The process of designing balanced scorecard method is based on the assumption that strategy is a hypothesis; it indicates the movement of organization from current situation to a desirable, but insecure situation in future, and since the organization has not been in future, the predesigned movement direction includes a set of related hypotheses (Kaplan \& Norton, 2004). Therefore, development and implementation of strategies, and organization's direction occur in an uncertain condition. Hence, we conclude that in today's competitive business environment with limited resources, organizations will not able to implement all of the developed strategies. Attempts to implement all developed strategies cause the dispersion of organization's resources, resulting in surrendering opportunities to competitors that have applied their scarce resources in a concentrated way. Clarifying the company's visions and strategy is the first step for achieving goals of balanced scorecard method. Unfortunately, balanced scorecard method is not able to measure and select suitable strategies by itself. To this end, we have tried to select the best strategies in an uncertain environment by presenting an algorithm, which is a combination of the concepts of integer non-linear multiple objective programming and fuzzy set covering.

\section{The proposed algorithm}

\subsection{Fuzzy set covering problem}

If $\tilde{P}_{j}$ is a fuzzy subset of $I$ set so that $\mu_{j}(i), \tilde{P}_{j}=\left\{\left(i, \mu_{j}(i)\right) \mid i \in I\right\}$ is used as membership function $i \in I$, then union of fuzzy sets will be as follows:

$$
\begin{aligned}
& \bigcup_{j=1}^{n} \tilde{P}_{j}=\left\{\left(i, \mu_{(1,2, \ldots, n)}(i)\right) \mid i \in I\right\}, \\
& \bigcup_{j=1}^{n} \tilde{p}_{j}\{(i,) \mid i \in I\}, \\
& \mu_{(1,2, \ldots, n)}(i)=1-\prod_{j=1}^{n}\left(1-\mu_{j}(i)\right) .
\end{aligned}
$$

The above-mentioned definition is a generalization of an algebraic addition of two fuzzy sets. There are many discussions about the algebraic of two sets that we can refer to Zimmermann (1996) and Terano et al (1992). The set $\tilde{\varphi}_{\alpha}=\left\{\tilde{P}_{j} \mid j \in J_{0}\right\}$ is called the fuzzy covering with degree $\alpha \in[0,1]$ or one $\alpha$-Cover whenever we have: 
$\forall i \in I: \bigcup_{j \in J_{0}} \tilde{P}_{J}=\left\{\left(i, \mu_{(1,2, \ldots, n)}(i)\right) \mid i \in I\right\}$

where

$\min _{i} \mu_{(1,2, \ldots, n)}(i)=\alpha, j \in J_{0}$

According to the above mentioned concepts, a fuzzy set covering problem (FSCP) refers to the finding an optimal of $\alpha$-Cover equal to $\tilde{\varphi}_{\alpha}$ for $I$ set and $\alpha$ utility degree presented so that for each $i \in I, i$ membership degree is not less than $\alpha$ degree level. For each $\tilde{P}_{j}$ fuzzy set of $I$, there is a $C_{j}$ positive number related to it. Therefore, we can formulate a fuzzy set covering problem as follows (Hwang et al., 2004; Chiang et al., 2005):

$\min \sum_{j=1}^{n} C_{j} X_{j}$

subject to

$$
\begin{array}{ll}
\sum_{j=1}^{n} X_{j}\left[-\ln \left(1-\mu_{j}(i)\right)\right] \geq-\ln (1-\alpha) & i=1,2, \ldots . m \\
X_{j}=\{0,1\} & j=1,2, \ldots . n \\
0<\alpha<1 &
\end{array}
$$

If we add minimizing function of judgments' standard deviation to Eq. (5), we will get a multiple objective programming problem, which can determine an acceptable combination of strategies with the most aggregative agreement, the least costs, and the most covering amount of criteria. This model is explained as follow.

$\min \sum_{i=1}^{n} \mu_{i} W_{i}, \quad \min \sum_{i=1}^{n} \sigma_{i} W_{i}, \quad \min \sum_{i=1}^{1} \sigma_{j}(1) W_{i}, \cdots, \min \sum_{i=1}^{n} \sigma_{j}(i) W_{i}$

subject to

$$
\begin{array}{ll}
\sum_{j=1}^{n} X_{j}\left[-\ln \left(1-\mu_{j}(i)\right)\right] \geq-\ln (1-\alpha) & i=1,2, \ldots . m \\
X_{j}=\{0,1\} & j=1,2, \ldots . n \\
0<\alpha<1 &
\end{array}
$$

\subsection{Implementation stages of proposed algorithm}

The descriptions of the algorithm presented in Fig. 1 in different steps are as follows,

Steps 1 and 2: Determining a list of strategies and criteria set: organizations at the strategy formulation step design their strategies by using of tools such as SWOT matrix. These strategies can be measured by specific criteria. Criteria can vary related to the activity environment and experts' opinions in each organization.

Step 3: choosing an expert team and surveying about the amount of covering criteria by strategies: an expert team or experts that know the organization and its processes well can do the best evaluation about strategies. Therefore, by choosing the expert team with above-mentioned characteristics, we can collect their ideas about each of strategies (considering covering criteria and implementation cost).

Step 4: Calculation of mean and standard deviation judgments: This step needs a combination of the expert team's opinions. We use arithmetic or geometric mean in accordance to calculation principles of fuzzy numbers.

Step 5: Defining integer non-linear programming problem: A kind of non-linear integer programming with zero and one variables is gained by interning the defuzzificated coefficients of 
strategies cost in goal function and defuzzicated coefficients of criteria cover set of strategies in constraints with considering the amount of utility degree. After minimizing it, we will reach a set of solutions that are specified as "first solution set" at chart (1). This solution set which is recognized at specific utility level can include an optimal combination of strategies.

Step 6: Defining non-linear multiple-objective integer programming problem: Although the combination of strategies from the last step can create the most cover of criteria with the least cost, but it may not be the best combination between the expert team in terms of the aggregative agreement. Therefore, by adding standard deviation of judgments for cost of strategies execution, using non-linear multiple-objective programming, we will find "the second solution set".

Step 7: Analysis of results: If there is a difference between the first and second solution sets, we conclude that there is a considerable difference between the expert team, requiring more investigation. Therefore we conduct the survey again more carefully. If the ideas change, the algorithm is repeated like chart (1), and if the expert team's solutions are approved, the best solution set will be the set that has the most aggregative agreement or the least standard deviation in judgment, then the second solution set is selected as the best combination for strategies.

Step 8: Ranking of strategies: The level of utility can vary related to the intra- and extraorganizational environmental conditions. One of the other use of mentioned algorithm is ranking of strategies. This ranking is gained by using of a change at utility level that can be a logical reason for prioritizing the strategies.

By applying the proposed algorithm in Islamic Azad University, Semnan Branch, the obtained results is analyzed.

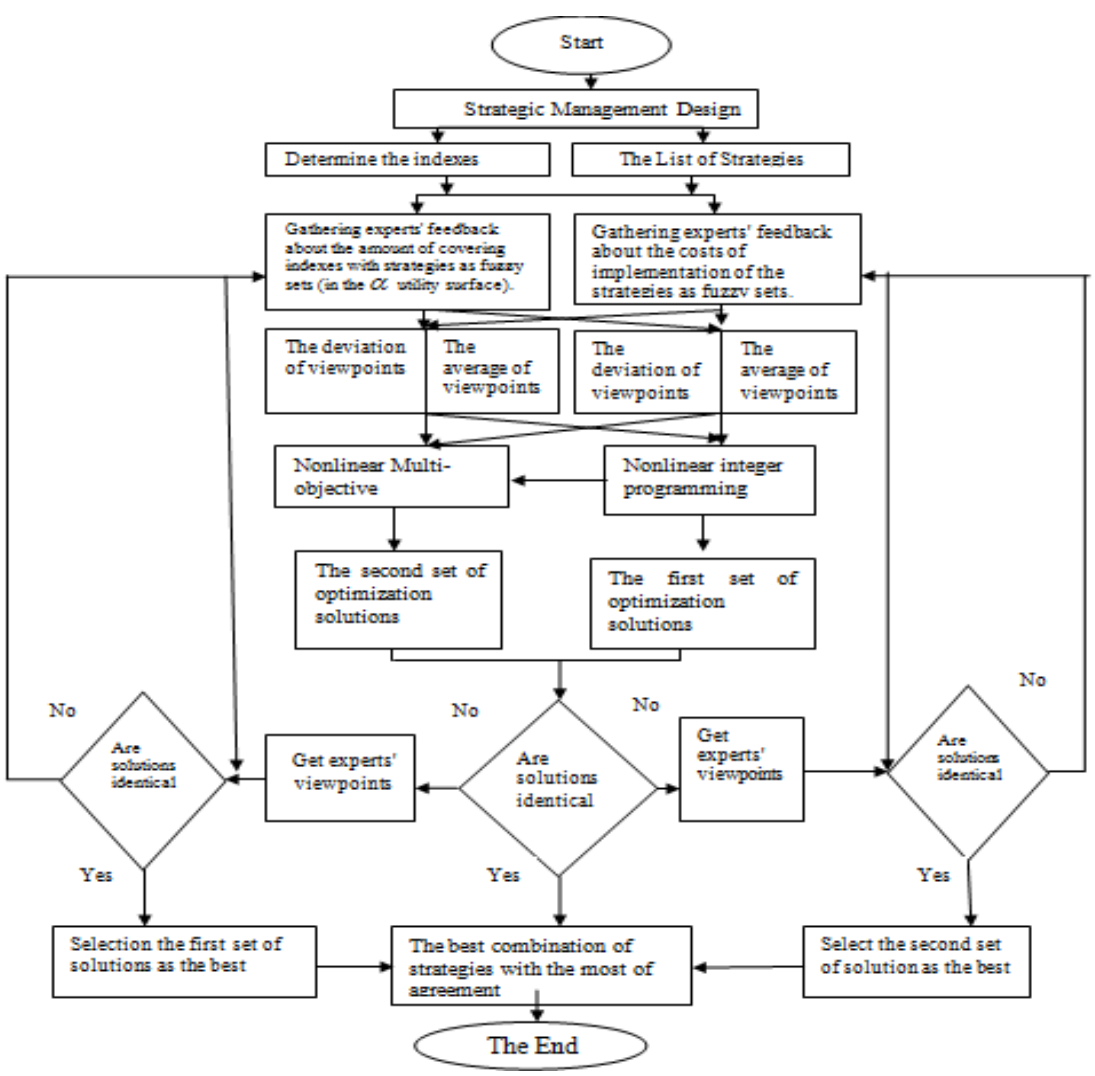

Fig. 1.The accomplishment steps of proposed algorithm 


\section{Data analysis}

According to the steps of proposed algorithm, designing the mentioned algorithm for Islamic Azad University, Semnan Branch is as follows:

Steps 1: By using SWOT matrix, the stated strategies for the university is as follows:

Strategy 1: Development of educational space (construction)

Strategy 2: Development of post graduation

Strategy 3: Development of technical fields at Bachelor of Science (B.S)

Strategy 4: Decreasing the financial dependence on students' tuition by increasing software and hardware abilities

Strategy 5: Correcting, revising and designing the university key processes in order to increase abilities to reply the university's new needs (For example: correction of payment system, correction of official structure, increasing the application of IT)

Strategy 6: Creation and development of Research \& Development centers in order to gain revenue through research activities (such as selling scientific patents)

Strategy 7: Improving educational quality

Strategy 8: Creating, keeping and developing of competitive advantage at least in one of the scientific, research or sport fields

Step 2: In this research, Porter's five criteria is used as strategies' measurement criteria, in which the expert team has assessed each one's level of coverage with discourse variables.

Step 3: In this Step, by using the questionnaire, the necessary information about the cost of strategies and the level of criteria's coverage by using expert team have been prepared.

According to 6 questions for covering Porter's five criteria and their cost, after combining the experts' opinions with calculation of geometric mean, the team's opinions for every level have been explained in Table 1 to Table 4.

The six questions are as follows:

1. How much do you assess the implementation cost for this strategy in a period of 4 years?

2. Does this strategy have a more competitive advantage rather than the strategies of competitors at the same period?

3. Can this strategy reduce or eliminate the threat of new entrants in this period?

4. Will this strategy be able to create a suitable reaction against substitution and similar services by competitors in the future?

5. Does this strategy have the ability to confront against bargaining power of users of the considered service?

6. Does this strategy have the ability to confront against bargaining power of the people who provide the necessary services for implementing the strategy? 
Table 1

Combined opinion of experts about the each of the strategies as fuzzy responses (Porter's five forces)

\begin{tabular}{|c|c|c|c|c|c|c|}
\hline Strategy variable & $\begin{array}{l}\text { The bargaining } \\
\text { power of suppliers }\end{array}$ & $\begin{array}{c}\text { The bargaining } \\
\text { power of customers } \\
\text { or buyers }\end{array}$ & $\begin{array}{l}\text { The threat of } \\
\text { substitute } \\
\text { products or } \\
\text { services } \\
\end{array}$ & $\begin{array}{l}\text { The threat } \\
\text { of new } \\
\text { entrants }\end{array}$ & $\begin{array}{l}\text { The intensity of } \\
\text { competitive } \\
\text { rivalry }\end{array}$ & $\begin{array}{l}\text { The } \\
\text { implementation } \\
\text { cost }\end{array}$ \\
\hline \multirow{3}{*}{$\mathrm{X}_{1}$} & 0.300 & 0.300 & 0.200 & 0.141 & 0.000 & 0.850 \\
\hline & 0.500 & 0.500 & 0.350 & 0.265 & 0.100 & 0.950 \\
\hline & 0.700 & 0.700 & 0.500 & 0.387 & 0.212 & 1.000 \\
\hline \multirow{3}{*}{$\mathrm{X}_{2}$} & 0.387 & 0.500 & 0.592 & 0.700 & 0.592 & 0.173 \\
\hline & 0.570 & 0.650 & 0.721 & 0.800 & 0.721 & 0.316 \\
\hline & 0.748 & 0.800 & 0.849 & 0.900 & 0.849 & 0.458 \\
\hline \multirow{3}{*}{$X_{3}$} & 0.458 & 0.387 & 0.592 & 0.458 & 0.387 & 0.387 \\
\hline & 0.632 & 0.570 & 0.721 & 0.632 & 0.570 & 0.570 \\
\hline & 0.794 & 0.748 & 0.849 & 0.794 & 0.748 & 0.748 \\
\hline \multirow{3}{*}{$\mathrm{X}_{4}$} & 0.592 & 0.652 & 0.700 & 0.700 & 0.652 & 0.000 \\
\hline & 0.721 & 0.786 & 0.800 & 0.800 & 0.786 & 0.132 \\
\hline & 0.849 & 0.894 & 0.900 & 0.900 & 0.894 & 0.274 \\
\hline \multirow{3}{*}{$\mathrm{X}_{5}$} & 0.387 & 0.458 & 0.700 & 0.652 & 0.592 & 0.000 \\
\hline & 0.570 & 0.632 & 0.800 & 0.786 & 0.721 & 0.158 \\
\hline & 0.748 & 0.794 & 0.900 & 0.894 & 0.849 & 0.324 \\
\hline \multirow{3}{*}{$\mathrm{X}_{6}$} & 0.592 & 0.500 & 0.700 & 0.700 & 0.652 & 0.316 \\
\hline & 0.721 & 0.650 & 0.800 & 0.800 & 0.786 & 0.477 \\
\hline & 0.849 & 0.800 & 0.900 & 0.900 & 0.894 & 0.632 \\
\hline \multirow{3}{*}{$\mathrm{X}_{7}$} & 0.592 & 0.592 & 0.592 & 0.505 & 0.458 & 0.245 \\
\hline & 0.721 & 0.721 & 0.721 & 0.689 & 0.632 & 0.418 \\
\hline & 0.849 & 0.849 & 0.849 & 0.837 & 0.794 & 0.592 \\
\hline \multirow{3}{*}{$\mathrm{X}_{8}$} & 0.592 & 0.700 & 0.771 & 0.771 & 0.850 & 0.316 \\
\hline & 0.721 & 0.800 & 0.872 & 0.872 & 0.950 & 0.477 \\
\hline & 0.849 & 0.900 & 0.949 & 0.949 & 1.000 & 0.632 \\
\hline
\end{tabular}

Step 4: After difuzzication and calculation of mean and standard deviation, we will get the Table 2 .

Table 2

Combined opinion of experts about each of the strategies as defuzzicated along with judgments' standard deviation

The Porter's five forces
The

implementation

cost

\begin{tabular}{|c|c|c|c|c|c|c|c|c|c|c|c|c|}
\hline \multirow[t]{2}{*}{ Strategy } & \multicolumn{2}{|c|}{$\begin{array}{l}\text { The bargaining } \\
\text { power of suppliers }\end{array}$} & \multicolumn{2}{|c|}{$\begin{array}{l}\text { The bargaining } \\
\text { power of } \\
\text { customers or } \\
\text { buyers }\end{array}$} & \multicolumn{2}{|c|}{$\begin{array}{l}\text { The threat of } \\
\text { substitute } \\
\text { products or } \\
\text { services }\end{array}$} & \multicolumn{2}{|c|}{$\begin{array}{c}\text { The threat of new } \\
\text { entrants }\end{array}$} & \multicolumn{2}{|c|}{$\begin{array}{c}\text { The intensity of } \\
\text { competitive } \\
\text { rivalry }\end{array}$} & \multirow[t]{2}{*}{$\begin{array}{l}\text { Standard } \\
\text { deviation }\end{array}$} & \multirow[t]{2}{*}{ Average } \\
\hline & $\begin{array}{l}\text { Standard } \\
\text { deviation }\end{array}$ & & $\begin{array}{l}\text { Standard } \\
\text { deviation }\end{array}$ & $\mathrm{Av}$ & $\begin{array}{l}\text { Standard } \\
\text { deviation }\end{array}$ & & $\begin{array}{l}\text { Standard } \\
\text { deviation }\end{array}$ & & $\begin{array}{l}\text { Standard } \\
\text { deviation }\end{array}$ & & & \\
\hline$\overline{X_{1}}$ & 0.007 & 0.500 & 0.007 & 0.500 & 0.004 & 0.350 & 0.003 & 0.264 & 0.002 & 0.104 & 0.001 & 0.933 \\
\hline$X_{2}$ & 0.005 & 0.569 & 0.004 & 0.650 & 0.003 & 0.720 & 0.002 & 0.800 & 0.003 & 0.720 & 0.003 & 0.316 \\
\hline $\mathrm{X}_{3}$ & 0.005 & 0.628 & 0.005 & 0.569 & 0.003 & 0.720 & 0.005 & 0.628 & 0.005 & 0.569 & 0.005 & 0.569 \\
\hline$X_{4}$ & 0.003 & 0.720 & 0.002 & 0.777 & 0.002 & 0.800 & 0.002 & 0.800 & 0.002 & 0.777 & 0.003 & 0.135 \\
\hline $\mathrm{X}_{5}$ & 0.005 & 0.569 & 0.005 & 0.628 & 0.002 & 0.800 & 0.002 & 0.777 & 0.003 & 0.720 & 0.004 & 0.161 \\
\hline$X_{6}$ & 0.003 & 0.720 & 0.004 & 0.650 & 0.002 & 0.800 & 0.002 & 0.800 & 0.002 & 0.777 & 0.004 & 0.475 \\
\hline $\mathrm{X}_{7}$ & 0.003 & 0.720 & 0.003 & 0.720 & 0.003 & 0.720 & 0.005 & 0.677 & 0.005 & 0.628 & 0.005 & 0.418 \\
\hline $\mathrm{X}_{8}$ & 0.003 & 0.720 & 0.002 & 0.800 & 0.001 & 0.864 & 0.001 & 0.864 & 0.001 & 0.933 & 0.004 & 0.475 \\
\hline
\end{tabular}


Step 5: In this step, the problem of selecting a suitable strategy is defined in the form of a fuzzy setcovering problem as to be non-linear integer programming with zero- and one-variable by choosing a level of utility for covering the criteria. The formulation of problem is as following:

$\min Z_{1}=0.933 X_{1}+0.316 X_{2}+0.569 X_{3}+0.135 X_{4}+0.161 X_{5}+0.475 X_{6}+0.418 X_{7}+0.475 X_{8}$ subject to

$$
\begin{aligned}
1) & -\ln (1-0.110) X_{1}-\ln (1-1.274) X_{2}-\ln (1-0.841) X_{3}-\ln (1-1.502) X_{4}-\ln (1-1.274) X_{5} \\
& -\ln (1-1.502) X_{6}-\ln (1-0.989) X_{7}-\ln (1-2.708) X_{8} \geq-\ln (1-\alpha) \\
2) & -\ln (1-0.307) X_{1}-\ln (1-1.609) X_{2}-\ln (1-0.989) X_{3}-\ln (1-1.609) X_{4}-\ln (1-1.502) X_{5} \\
& -\ln (1-1.609) X_{6}-\ln (1-1.130) X_{7}-\ln (1-1.995) X_{8} \geq-\ln (1-\alpha) \\
3) & -\ln (1-0.431) X_{1}-\ln (1-1.274) X_{2}-\ln (1-1.274) X_{3}-\ln (1-1.609) X_{4}-\ln (1-1.609) X_{5} \\
& -\ln (1-1.609) X_{6}-\ln (1-1.274) X_{7}-\ln (1-1.995) X_{8} \geq-\ln (1-\alpha) \\
4) & -\ln (1-0.693) X_{1}-\ln (1-1.050) X_{2}-\ln (1-0.841) X_{3}-\ln (1-1.502) X_{4}-\ln (1-0.989) X_{5} \\
& -\ln (1-1.050) X_{6}-\ln (1-1.274) X_{7}-\ln (1-1.609) X_{8} \geq-\ln (1-\alpha) \\
5) & -\ln (1-0.693) X_{1}-\ln (1-0.841) X_{2}-\ln (1-0.989) X_{3}-\ln (1-1.274) X_{4}-\ln (1-0.841) X_{5} \\
- & \ln (1-1.274) X_{6}-\ln (1-1.274) X_{7}-\ln (1-1.274) X_{8} \geq-\ln (1-\alpha) \\
X_{j} & =0 \text { or } 1 \quad j=1,2, \ldots . n \quad a=0.999
\end{aligned}
$$

By solving the above nonlinear integer programming, we have achieved the following set of solutions:

Table 3

\begin{tabular}{|c|c|c|c|c|c|c|c|c|c|c|c|c|}
\hline \multirow[t]{2}{*}{$\overline{\text { Strategy }}$} & \multicolumn{2}{|c|}{$\begin{array}{l}\text { The bargaining } \\
\text { power of suppliers }\end{array}$} & \multicolumn{2}{|c|}{$\begin{array}{l}\text { The bargaining } \\
\text { power of } \\
\text { customers or } \\
\text { buyers }\end{array}$} & \multicolumn{2}{|c|}{$\begin{array}{c}\text { The threat of } \\
\text { substitute products } \\
\text { or services }\end{array}$} & \multicolumn{2}{|c|}{$\begin{array}{c}\text { The threat of new } \\
\text { entrants }\end{array}$} & \multicolumn{2}{|c|}{$\begin{array}{l}\text { The intensity of } \\
\text { competitive } \\
\text { rivalry }\end{array}$} & \multirow[t]{2}{*}{$\begin{array}{l}\text { Standard } \\
\text { deviation }\end{array}$} & \multirow[t]{2}{*}{ Average } \\
\hline & $\begin{array}{l}\text { Standard } \\
\text { deviation }\end{array}$ & & $\begin{array}{l}\text { Standard } \\
\text { deviation }\end{array}$ & Ave & $\begin{array}{l}\text { Standard } \\
\text { deviation }\end{array}$ & Ave & $\begin{array}{l}\text { Standard } \\
\text { deviation }\end{array}$ & & $\begin{array}{l}\text { Standard } \\
\text { deviation }\end{array}$ & & & \\
\hline $\mathrm{X}_{1}$ & 0.007 & 0.500 & 0.007 & 0.500 & 0.004 & 0.350 & 0.003 & 0.264 & 0.002 & 0.104 & 0.001 & 0.933 \\
\hline$X_{2}$ & 0.005 & 0.569 & 0.004 & 0.650 & 0.003 & 0.720 & 0.002 & 0.800 & 0.003 & 0.720 & 0.003 & 0.316 \\
\hline$X_{3}$ & 0.005 & 0.628 & 0.005 & 0.569 & 0.003 & 0.720 & 0.005 & 0.628 & 0.005 & 0.569 & 0.005 & 0.569 \\
\hline $\mathrm{X}_{4}$ & 0.003 & 0.720 & 0.002 & 0.777 & 0.002 & 0.800 & 0.002 & 0.800 & 0.002 & 0.777 & 0.003 & 0.135 \\
\hline $\mathrm{X}_{5}$ & 0.005 & 0.569 & 0.005 & 0.628 & 0.002 & 0.800 & 0.002 & 0.777 & 0.003 & 0.720 & 0.004 & 0.161 \\
\hline$X_{6}$ & 0.003 & 0.720 & 0.004 & 0.650 & 0.002 & 0.800 & 0.002 & 0.800 & 0.002 & 0.777 & 0.004 & 0.475 \\
\hline $\mathrm{X}_{7}$ & 0.003 & 0.720 & 0.003 & 0.720 & 0.003 & 0.720 & 0.005 & 0.677 & 0.005 & 0.628 & 0.005 & 0.418 \\
\hline $\mathrm{X}_{8}$ & 0.003 & 0.720 & 0.002 & 0.800 & 0.001 & 0.864 & 0.001 & 0.864 & 0.001 & 0.933 & 0.004 & 0.475 \\
\hline
\end{tabular}

Set of solutions for non-linear integer programming with $99.9 \%$ of utility level

\begin{tabular}{rlllllll}
\hline $\mathrm{Z}_{1}=2.233$ & $\mathrm{X}_{1}=0$ & $\mathrm{X}_{2}=0$ & $\mathrm{X}_{3}=1$ & $\mathrm{X}_{4}=1$ & $\mathrm{X}_{5}=1$ & $\mathrm{X}_{6}=1$ & $\mathrm{X}_{7}=1$ \\
$\mathrm{X}_{8}=1$ & $\alpha=99.9 \%$ & & & & & & \\
\hline
\end{tabular}

Step 6: Considering the standard deviation of the judgments in Table 2, we get Table 4 as the following:

Table 4

Combined opinion of experts about the each of the strategies which is defuzzicated, with judgments' standard deviation

The Porter five forces

implementation

cost

So that to formulate the data in the form of non-linear multiple objective integer programming we will have: 
$\min Z_{1}=0.933 X_{1}+0.316 X_{2}+0.569 X_{3}+0.135 X_{4}+0.161 X_{5}+0.475 X_{6}+0.418 X_{7}+0.475 X_{8}$ $\min Z_{2}=0.001 X_{1}+0.003 X_{2}+0.005 X_{3}+0.003 X_{4}+0.004 X_{5}+0.004 X_{6}+0.005 X_{7}+0.004 X_{8}$ $\min Z_{3}=0.002 X_{1}+0.003 X_{2}+0.005 X_{3}+0.002 X_{4}+0.003 X_{5}+0.002 X_{6}+0.005 X_{7}+0.001 X_{8}$ $\min Z_{4}=0.003 X_{1}+0.002 X_{2}+0.005 X_{3}+0.002 X_{4}+0.002 X_{5}+0.002 X_{6}+0.005 X_{7}+0.001 X_{8}$ $\min Z_{5}=0.004 X_{1}+0.003 X_{2}+0.003 X_{3}+0.002 X_{4}+0.002 X_{5}+0.002 X_{6}+0.003 X_{7}+0.001 X_{8}$ $\min Z_{6}=0.007 X_{1}+0.004 X_{2}+0.005 X_{3}+0.002 X_{4}+0.005 X_{5}+0.004 X_{6}+0.003 X_{7}+0.002 X_{8}$ $\min Z_{7}=0.007 X_{1}+0.005 X_{2}+0.005 X_{3}+0.003 X_{4}+0.005 X_{5}+0.003 X_{6}+0.003 X_{7}+0.003 X_{8}$ subject to

1) $0.110 X_{1}+1.274 X_{2}+0.841 X_{3}+1.502 X_{4}+1.274 X_{5}+1.502 X_{6}+0.989 X_{7}+2.708 X_{8} \geq-\ln (1-\alpha)$

2) $0.307 X_{1}+1.609 X_{2}+0.985 X_{3}+1.609 X_{4}+1.502 X_{5}+1.609 X_{6}+1.130 X_{7}+1.995 X_{8} \geq-\ln (1-\alpha)$

3) $0.431 X_{1}+1.274 X_{2}+1.274 X_{3}+1.609 X_{4}+1.609 X_{5}+1.609 X_{6}+1.274 X_{7}+1.995 X_{8} \geq-\ln (1-\alpha)$

4) $0.693 X_{1}+1.050 X_{2}+0.841 X_{3}+1.502 X_{4}+0.989 X_{5}+1.050 X_{6}+1.274 X_{7}+1.609 X_{8} \geq-\ln (1-\alpha)$

5) $0.693 X_{1}+0.841 X_{2}+0.989 X_{3}+1.274 X_{4}+0.841 X_{5}+1.274 X_{6}+1.274 X_{7}+1.274 X_{8} \geq-\ln (1-\alpha)$

$$
x_{j}=0 \text { or } 1 \quad j=1,2, \ldots . n \quad \alpha=[0,1]
$$

After solving in different levels of utility, we will accomplish to the same solution in Table 3.

Step 7: since the optimal set of solutions (first set of solutions) and acceptable set of solutions (second set of solutions) are similar, we can conclude that the introduced strategies can cover most of the criteria with the least cost with the most aggregative agreement.

Step 8: If we solve the discussed nonlinear integer programming problems with various level of utilities, then we will have:

\section{Table 5}

Nonlinear integer programming solution set with various utilities

\begin{tabular}{lcccc}
\hline$\alpha=99 \%$ & $\alpha=95 \%$ & $\alpha=90 \%$ & $\alpha=85 \%, 80 \%, 75 \%$ & $\alpha=70 \%, \ldots, 10 \%$ \\
\hline $\mathrm{Z}_{1}=1.189$ & $\mathrm{Z}_{1}=0.714$ & $\mathrm{Z}_{1}=0.553$ & $\mathrm{Z}_{1}=0.296$ & $\mathrm{Z}_{1}=0.135$ \\
$\mathrm{X}_{1}=0$ & $\mathrm{X}_{1}=0$ & $\mathrm{X}_{1}=0$ & $\mathrm{X}_{1}=0$ & $\mathrm{X}_{1}=0$ \\
$\mathrm{X}_{2}=0$ & $\mathrm{X}_{2}=0$ & $\mathrm{X}_{2}=0$ & $\mathrm{X}_{2}=0$ & $\mathrm{X}_{2}=0$ \\
$\mathrm{X}_{3}=0$ & $\mathrm{X}_{3}=0$ & $\mathrm{X}_{3}=0$ & $\mathrm{X}_{3}=0$ & $\mathrm{X}_{3}=0$ \\
$\mathbf{X}_{\mathbf{4}}=\mathbf{1}$ & $\mathbf{X}_{\mathbf{4}}=\mathbf{1}$ & $\mathbf{X}_{\mathbf{4}}=\mathbf{1}$ & $\mathbf{X}_{\mathbf{4}}=\mathbf{1}$ & $\mathbf{X}_{\mathbf{4}}=\mathbf{1}$ \\
$\mathbf{X}_{\mathbf{5}}=\mathbf{1}$ & $\mathbf{X}_{\mathbf{5}}=\mathbf{1}$ & $\mathrm{X}_{5}=0$ & $\mathrm{X}_{5}=0$ & $\mathrm{X}_{5}=0$ \\
$\mathbf{X}_{\mathbf{6}}=\mathbf{1}$ & $\mathrm{X}_{6}=0$ & $\mathrm{X}_{6}=0$ & $\mathrm{X}_{6}=0$ & $\mathrm{X}_{6}=0$ \\
$\mathbf{X}_{\mathbf{7}}=\mathbf{1}$ & $\mathbf{X}_{\mathbf{7}}=\mathbf{1}$ & $\mathbf{X}_{\mathbf{7}}=\mathbf{1}$ & $\mathbf{X}_{\mathbf{7}}=\mathbf{1}$ & $\mathrm{X}_{7}=0$ \\
$\mathrm{X}_{8}=0$ & $\mathrm{X}_{8}=0$ & $\mathrm{X}_{8}=0$ & $\mathrm{X}_{8}=0$ & $\mathrm{X}_{8}=0$ \\
\hline
\end{tabular}

With reference to the Table 5, we show the high uniformity of solutions.

\section{Discussion and Conclusion}

According to the presented model for accomplishing an optimal combination of strategies, the results in the confidence level of $100 \%(\alpha=99.9 \% \cong 100 \%)$ the effective strategies are:

Strategy 3: Development of engineering courses at B.S. level

Strategy 4: Decreasing the financial dependence on student's tuition through increasing the software and hardware abilities 
Strategy 5: Correction, review and reengineering the key university processes again to increase the abilities respond effectively to university new needs (like correction of payment system, correction of official structure, and increase in IT usage)

Strategy 6: Creation and development of Research \& Development centers in order to earn income through research activities (Such as selling scientific patents)

Strategy 7: Improvement of quality of education

Strategy 8: Creation, keeping and development of competitive advantage at least in one of the scientific, research or sport domains.

What is noticeable is that two strategies "Development of educational space (construction)" and "development of Post-graduation" were not selected as efficient strategies. One of the main reasons for it is that selections were done according to the cost criteria so that the results indicate the selected strategies are the optimal combination, because it can create the most efficiency with the least amount of cost as a future view for organization.

The costs level or expected budget for implementing such strategies is more than $\$ 22$ million, which it is not reasonable for a university to operate at a four-year program. Therefore, by reduction of environmental confidence level (restrictions of internal environment) we decrease the strategies. This process is repeated for confidence level of $99 \%$. The results are repeated compared with the last step by elimination of the strategies 3 and 8 . By eliminating these two strategies, the acquired budget will diminish to about $\$ 12$ million $(11,890,000)$ (According to the costs level determined for a university that is equal to $\$ 120$ million, this set of strategies can be the most optimal combination that is possible.

Furthermore, based on the forth results, we have achieved the same conclusion as the last single objective model by using six function of minimizing goal of standard deviation of the judgments. This indicates aggregative consent of the expert team about the set of selected strategies.

Moreover, by reducing the confidence level to $10 \%$, the result in all steps of choosing the forth strategy was "decrease of financial dependence on student's tuition through increase in software and hardware abilities". This can certify the importance of this strategy in all conditions (from complete high level of confidence level to the lowest level of confidence). Moreover, if we would like to prioritize the strategies according to their importance according to the conclusions in step 8 , we get the following priorities.

Table 6

The states of strategies membership in functions with various utilities

\begin{tabular}{|c|c|c|c|c|c|c|c|c|}
\hline $\begin{array}{l}\text { The confidence } \\
\text { surface } \\
\text { Strategy }\end{array}$ & Rank & $\begin{array}{l}\text { The sum of } \\
\text { scores }\end{array}$ & $\begin{array}{l}0.10 \\
\text { until } \\
0.70 \\
\end{array}$ & $\begin{array}{l}0.75 \text { until } \\
\quad 0.85\end{array}$ & 0.90 & 0.95 & 0.99 & 0.999 \\
\hline$\overline{X_{1}}$ & 6 & 0 & & & & & & \\
\hline$X_{2}$ & 6 & 0 & & & & & & \\
\hline $\mathrm{X}_{3}$ & 5 & 1 & & & & & & $\sqrt{ }$ \\
\hline$X_{4}$ & 1 & 6 & $\sqrt{ }$ & $\sqrt{ }$ & $\sqrt{ }$ & $\sqrt{ }$ & $\sqrt{ }$ & $\sqrt{ }$ \\
\hline $\mathrm{X}_{5}$ & 2 & 4 & & $\sqrt{ }$ & & $\sqrt{ }$ & $\sqrt{ }$ & $\sqrt{ }$ \\
\hline $\mathrm{X}_{6}$ & 4 & 2 & & & & & $\sqrt{ }$ & $\sqrt{ }$ \\
\hline$X_{7}$ & 3 & 4 & & & $\sqrt{ }$ & $\sqrt{ }$ & $\sqrt{ }$ & $\sqrt{ }$ \\
\hline $\mathrm{X}_{8}$ & 5 & 1 & & & & & & $\sqrt{ }$ \\
\hline
\end{tabular}

Considering the strategies of Islamic Azad University, Semnan branch, we can present the following use for the purposed algorithm: 
1. If we combine it with balanced scorecard model, it will increase the efficiency of this model by eliminating the non-efficient strategies.

2. Increasing of the attention to surveys with standard deviation of judgments by comparing the problem's optimal and accepted solutions set and examining the current contrasts.

3. The possibility of making the best decision in conditions of uncertainty for collection of strategies

4. Priority of strategies with the reliability criteria in different environmental conditions (with various utilities' coefficient functions) which have stronger reasons compared to the current traditional methods like pair comparisons

\section{Acknowledgment}

The present study has accomplished using a great support and cooperation of the officials of the Islamic Azad University, Semnan branch and the authors would like to thank them. The authors would like to thank the anonymous referees for their constructive comments on earlier version of this work.

\section{References}

Baldwin, C.Y., \& Clark, K.B. (1992). Capabilities and Capital Investment: New Perspectives on Capital Budgeting. Journal of Applied Corporate Finance, 5(2), 67-82.

Chiang, C.I., Hwang, M.J., \& Liu, Y.H. (2005). An Alternative Formulation for Certain Fuzzy SetCovering Problems. Mathematical and Computer Modeling, 42(3-4), 363-365.

Gumbus, A. (2005). Introducing the Balanced Scorecard: Creating Metrics to Measure Performance. Journal of Management Education, 29(4), 617-630.

Hwang, M.J., Chiang, C.I., \& Liu, Y.H. (2004). Solving a Fuzzy Set-Covering Problem. Mathematical and Computer Modeling, 40, (7-8), 861-865.

Kaplan, R.S., \& Norton, D.P. (2001). The strategy-focused organization: How balanced scorecard companies thrive in the new business environment. Harvard Business School Press, Boston.

Kaplan, R. S., \& Norton, D.P. (1996). Using the balanced scorecard as a strategic measurement system. Harvard Business Review, 74(1), 75-85.

Kaplan, R. S., \& Norton, D.P. (2004). Strategy Maps: Converting Intangible Assets into Tangible Outcomes, Harvard Business School Press, Boston.

Lee, S. F, \& Ko, A. S. (2000). Building balanced scorecard with SWOT analysis and implementing "Sun Tzu's the Art of Business Management Strategy" On QFD Methodology. Managerial Auditing Journal, 15(1/2), 68-76.

Niven, P. R. (2003). Balanced Scorecard Step-by-Step For Government And Nonprofit Agencies. John Wiley and Sons, New Jersey.

Terano, T., Asai, K., \& Sugeno, M. (1992), Fuzzy systems Theory and Its Applications, Academic Press, Boston.

Wilson, A. (2004). How process defines performance management. International Journal of Productivity and Performance Management, 53(3), 261-267.

Zimmermann, H.J. (1996). Fuzzy set Theory and its Applications, $3^{\text {rd }}$ ed., Kluwer Academic Publishers, Boston.

Tseng, M. L., \& Lin, Y. H. (2009). Application of fuzzy DEMATEL to develop a cause and effect model of municipal solid waste management in Metro Manila. Environmental Monitoring and Assessment, 158, 519-533.

Tseng, M. L. (2010). Implementation and performance evaluation using the fuzzy network balanced scorecard. Computer \& Education, 55(1), 188-201.

Tseng, M. L. (2009). Application of ANP and DEMATEL to evaluate the decision-making of municipal solid waste management in Metro Manila. Environmental monitoring and assessment, 
156(1-4), 181-197.

Tseng, M. L., Lin, Y. H., Chiu, A. S. F., \& Liao, C. H. (2008). Using FANP approach on selection of competitive priorities based on cleaner production implementation: a case study in PCB manufacturer. Taiwan Clean Technologies and Environmental Policy, 10(1), 17-29.

Tseng, M. L., Chiang, J. H., \& Lan, W. L. (2009). Selection of optimal supplier in supply chain management strategy with analytic network process and choquet integral. Computer \& Industrial Engineering, 57(1), 330-340. 